
\title{
nombalina
}

(8)

História literária e personagens da história: os mártires da literatura

Autor(es): $\quad$ Reis, Carlos

Publicado por: Imprensa da Universidade de Coimbra

URL persistente:

URI:http://hdl.handle.net/10316.2/38683

DOI:

DOI:http://dx.doi.org/10.14195/978-989-26-1164-8_5

Accessed : $\quad$ 26-Apr-2023 02:33:31

A navegação consulta e descarregamento dos títulos inseridos nas Bibliotecas Digitais UC Digitalis, UC Pombalina e UC Impactum, pressupõem a aceitação plena e sem reservas dos Termos e Condições de Uso destas Bibliotecas Digitais, disponíveis em https://digitalis.uc.pt/pt-pt/termos.

Conforme exposto nos referidos Termos e Condições de Uso, o descarregamento de títulos de acesso restrito requer uma licença válida de autorização devendo o utilizador aceder ao(s) documento(s) a partir de um endereço de IP da instituição detentora da supramencionada licença.

Ao utilizador é apenas permitido o descarregamento para uso pessoal, pelo que o emprego do(s) título(s) descarregado(s) para outro fim, designadamente comercial, carece de autorização do respetivo autor ou editor da obra.

Na medida em que todas as obras da UC Digitalis se encontram protegidas pelo Código do Direito de Autor e Direitos Conexos e demais legislação aplicável, toda a cópia, parcial ou total, deste documento, nos casos em que é legalmente admitida, deverá conter ou fazer-se acompanhar por este aviso. 
Carlos Reis

Universidade de Coimbra / Centro de Literatura Portuguesa

\section{HISTÓRIA LITERÁRIA E PERSONAGENS DA HISTÓRIA: OS MÁRTIRES DA LITERATURA}

0. Em "História Literária e Personagens da História" procuro conjugar dois campos de análise: o da história literária, enquanto disciplina antiga, já renovada e agora revisitada; o da teoria e análise da personagem, entendendo-se que esta categoria da narrativa indiretamente pode ser e tem sido objeto de atenção da história literária, tanto em termos temáticos como em termos procedimentais. Tratarei, assim, de observar e de comentar criticamente essa relação, visando os problemas levantados por personagens construídas a partir de figuras históricas, sendo algumas dessas figuras históricas escritores. O que me leva a recolocar, em diferentes contextos ideológicos, culturais e mesmo pedagógicos, o trabalho da história literária, formulando questões de ordem metodológica e epistemológica que ajudam a traçar o destino da disciplina.

1. Parto de quatro tópicos conducentes aos temas que mencionei. Primeiro, a lógica da paridade na história literária; segundo, alguns pecados da história literária, já penitenciados e absolvidos; terceiro, a articulação com os estudos narrativos, que é uma minha conveniência estratégica; quarto, duas especificações conceptuais que estabelecerei antes de avançarmos.

Falo aqui em lógica da paridade a partir de uma reflexão que há alguns anos empreendi e que era sugerida por este título: "It Takes Two to Tango: A Construção da Memória Literária”. Tratava-se de analisar uma certa forma de delinear a

\footnotetext{
1 Publicado em Maria da Penha Campos Fernandes (coord.), História(s) da Literatura: atas do $1^{\circ}$ Congresso Internacional de Teoria da Literatura e Literaturas Lusófonas. Coimbra: Almedina, 2005.
} 
história da literatura e o imaginário que ela convoca, tomando como mote um texto de Vergílio Ferreira, inserto num dos volumes do seu diário Conta Corrente:

10 - abril (quarta). Curiosa coisa - mas não sei se já o disse - é que a nossa literatura é feita largamente aos pares. Alguns serão absurdos, mas aos pares é que estão bem. Serão efeito das velas de um altar? ou de um defunto, que pode também ter 4? das leis de oposição? das leis do encosto? de uma lei metafísica dos números? O corpo humano tem órgãos pares mas também ímpares. Enfim, não entendo. A verdade é que o número par na literatura é abundante. Plutarco deu o exemplo e nós foi só copiar. Assim, logo já para trás, o Fernão Lopes e o Zurara. Depois o Gil Vicente e o Bernardim, que se emparelhou decerto pelo contraste como o preto e o branco. Depois Bocage e Filinto, Herculano e Garrett, Camilo e Eça, Cesário e Nobre, Pessoa e Sá-Carneiro, Aquilino e Ferreira de Castro, Régio e Torga, Redol e Soeiro, e hoje, enfim, ao que já ouvi a Agustina e eu. (...) Tudo isto deve ter um significado. A ver se o descubro. ${ }^{2}$

Uma hipótese de significado que coloquei e em que insisto: o equilíbrio que rege o princípio da paridade (ou do par) condiciona uma certa conformação histórico-literária e pré-determina o nosso imaginário cultural. Outra hipótese: a dualidade do par pode instaurar uma dinâmica de oposição e mesmo de conflitualidade, capaz de ser entendida, por outro lado, como tendência para a complementaridade: a referida "lei do encosto". Como quer que seja, parece cómodo configurar a história literária através da redução a imagens fixadas com intuitos primordialmente pedagógicos, mas com consequências inevitáveis a outros níveis. Por exemplo: o da constituição do cânone, em associação com a sedimentação da nossa memória coletiva e dos valores a que ela se reporta. ${ }^{3}$

2 Vergílio Ferreira, Conta-corrente, nova série, III, Lisboa, Bertrand, 1994, p. 90.

3 Chamo a atenção para estas palavras: "For literary history, in defining a relation of our present to a past, functions as a mode of social memory, and the different generic categories define different modes of memory, as they specify what values we associate a work with in remembering it and what other materials we link it with in our remembrance" (J. Arac, "What is the History of Literature", in Marshal Brown (ed.), The Uses of Literary History. Durham and London: Duke Univ. Press, 1995, p. 30. 
Segundo tópico: o dos pecados da história literária, amargamente vividos e testemunhados pela minha geração, essa que, lá pelos anos 60 e 70 do século passado, tratou de matar o autor para ressuscitar o texto. Dito desta forma simplificada parece fácil, mas convém não esquecer que os tais anos 60 não foram amenos, do ponto de vista da epistemologia dos estudos literários; e a tal geração belicosa tinha, afinal, boas razões para fazer o que fez. Algum do ensino da literatura que então se praticava era em grande parte biografista, fundado em modelos oitocentistas herdados de Sainte-Beuve e de Gustave Lanson, sobrecarregado de minudentes questões anedóticas (Gil Vicente nasceu onde, afinal? Terrível e irresolvida questão...), era causalista e duplamente finalístico. E assim, a história da literatura parecia caminhar para um fim (um final feliz, esperava-se), ao mesmo tempo que escondia um outro fim (uma finalidade), este nada cândido, de intuito ideológico e legitimador. A história literária, em suma, discriminava: separava e escolhia, mas não de forma inocente. À imagem do par (recordo: "it takes two to tango") outra vinha, então, juntar-se, esta mais cinematográfica: a dos "good guys" e dos "bad guys". Entretanto e para que conste: depois daquela morte anunciada, o autor ressuscitou e está de boa saúde.

Terceiro tópico: com a ajuda daquela imagem cinematográfica, encaminho a reflexão acerca da história literária para o domínio dos estudos narrativos, em parte, confesso, por ser este um dos meus campos de trabalho prioritários. A esta razão estimável mas talvez insuficiente, junto outra, mais lógica: se tudo são, afinal, histórias, a da literatura e as que a literatura conta, então sejam todas elas acolhidas no regaço plural e teoricamente muito amplo dos estudos narrativos. E fiquem à vontade, até por serem os estudos narrativos uma disciplina que se flexibilizou e abriu a campos de análise que estão já para além da ortodoxia genettiana (ortodoxia que foi necessária, note-se) e da sua coorte de seguidores, incluindo o autor deste texto. Antecipando um pouco do que aí vem: para a história literária pura e dura, quem é mais personagem, Miguel de Cervantes ou Dom Quixote? Flaubert ou Madame Bovary? Tolstoi ou Anna Karenina? E assim por diante.

Último tópico, porventura dispensável: distingo história literária de história da literatura - ou melhor, histórias da literatura. Como quem diz: falo na história literária como disciplina e método de trabalho, com os seus avanços e os seus recuos, as suas operações e as suas ferramentas, os seus doutrinadores e os seus cultores (por exemplo: a história literária lansoniana); e falo na história da 
literatura como sua concretização, normalmente corporizada em grossos volumes que incidem sobre uma literatura específica. É o caso da Histoire de la littérature anglaise de Taine, da História da literatura brasileira de Massaud Moisés ou da História da literatura portuguesa de António José Saraiva e Óscar Lopes. ${ }^{4}$

2. Posto isto, vejamos alguma coisa daquilo de que aqui se fala. Por outras palavras: lembremos o que pode ser visto em retratos de Camões, alguns bem conhecidos, que destaco do conjunto da sua vasta iconografia; são esses retratos que, provindos do imaginário camoniano, acabam por retroalimentar e por ampliar esse imaginário, com incidências certas no campo da história literária. Assim:

I. Numa imagem policromática de autoria desconhecida e datada de 1556, surge-nos Camões na prisão de Goa, aparentemente em posição de escrita;

II. O retrato de Camões por Fernão Gomes, conhecido como "retrato pintado a vermelho", foi também elaborado em vida do poeta (provavelmente entre 1573 e 1575) e é uma imagem por assim dizer canónica, mesmo tendo sido rasgado e grosseiramente reparado;

III. Deste retrato existe uma cópia por Luís José Pereira de Resende (1760-1847), cópia que, à distância de muitos anos, por assim dizer "restaurou" o mal conservado retrato anterior;

Iv. A imagem de Camões por François Gérard (1770-1837) representa o escritor com coroa de louros, revestido de armadura e com a mão direita segurando Os Lusíadas; é outra imagem canónica e muito difundida, acentuando a dualidade do poeta-soldado;

4 Aquelas são típicas histórias da literatura de autor, em vários aspetos distintas das que David Perkins designa como pós-modernas: a Columbia Literary History of the United States (ed. Emory Elliott and alii. New York: Columbia Univ. Press, 1987) ou A New History of French Literature (ed. Denis Hollier. Cambridge: Harvard Univ. Press, 1989), ambas constituídas por ensaios autónomos e sem preocupação de coerência ou sucessividade cronológica (cf. D. Perkins, Is Literary History Possible? Baltimore and London: The Johns Hopkins Univ. Press, 1992, pp. 3 e 56-59). Diferentemente destas, as histórias a que chamamos críticas combinam a história literária propriamente dita com as aproximações críticas a que autores, períodos e estilos literários têm dado lugar. Cf. Francisco Rico (org.), História y crítica de la literatura española. Barcelona: Crítica, 1980-1983, 9 vols.; C. Reis (org.), História crítica da literatura portuguesa. Lisboa: Verbo, 1995-.... (oito volumes publicados, de um total de nove). Acerca de vários aspetos da teoria, da prática e da epistemologia da historiografia literária, em particular no Brasil, remeto para dois volumes organizados por Maria Eunice Moreira: Histórias da literatura: teorias, temas e autores. Porto Alegre: Mercado Aberto, 1983; Histórias da literatura: teorias e perspetivas. Porto Alegre: EDIPUCRS, 2010. 
v. De 1817 é uma gravura de Desenne, que situa Camões na gruta de Macau, ou seja, no exotismo e na distância do Oriente que tanto marcou o trajeto pessoal do poeta e também o que nele há de lendário;

vi. De 1856 é o Camões náufrago da autoria de P. Morgari, representando o poeta apoiado a um rochedo, com a espada na mão esquerda e com um manuscrito (Os Lusíadas, naturalmente) na mão direita bem erguida; completa-se assim a dualidade do poeta-soldado com a arriscada condição do náufrago;

viI. O pintor José Malhoa (1855-1933) compôs um retrato de Camões em pose altiva, com vestimenta escura, capa curta e chapéu na mão direita, retrato cuja feição um tanto idealizada destoa da crueza realista de outras telas do pintor;

VIII. De outra natureza é o retrato composto pelo ator António Vilar para o filme Camões, obra com a marca ideológica do salazarismo, realizada por Leitão de Barros em 1946, que assim confirmou uma espécie de aforismo: a vida de Camões dava um filme - e deu mesmo.

Não faltam interrogações, lacunas e invenções na iconografia camoniana, em boa parte estudadas e desmontadas com paciente minúcia por investigadores dedicados: destaco aqui o trabalho de referência de B. Xavier Coutinho, Camões e as artes plásticas 5 , e também um livro de Aníbal Almeida, cujo contributo para a matéria se orienta para o desenho possível do "rosto de Camões, vibrante e expressivo, tão cruelmente devastado pela fúria cega do 'pátrio Marte' duvidoso (...); esse Camões de carne e osso cuja figura ou gesto se nos vai desvelando, não obstante o processo já multissecular de desenvolvimento de uma tendência para a diluição sistemática da sua imagem material". . Pouco faltou (comento eu) para ser esta uma figura sem imagem física; ou então e por isso mesmo, com tantas imagens quantas alcançou o engenho de historiadores e de ficcionistas. Uma verdadeira personagem em potência, pode dizer-se, sem exagero, personagem em quem não faltam, todavia, sugestões de caracterização e até de autocaracterização que a história literária normalmente recolhe em termos literais. Por exemplo: as dominantes do poeta-soldado, náufrago e abandonado pela

5 B. Xavier Coutinho, Camões e as artes plásticas. Subsídios para a iconografia camoniana. Porto: Liv. Figueirinhas, 1946-48, 2 vols.

6 Aníbal Almeida, O Rosto de Camões. Lisboa: Imprensa Nacional-Casa da Moeda, 1996, p. 99. 
fortuna, génio incompreendido, perseguido e exilado 7 , para mais marcado pela mutilação física, que o deformou, mas também singularizou de uma forma que chega a ser caricatural. O "olho à Camões" transformou-se até num tópico quase satírico da imagística portuguesa, muito para além do episódio e da figura que o originaram. Tudo isto por junto fundamenta o que um dia declarou Jorge Luis Borges: "Existe algo de misterioso em Camões, não apenas no seu destino, mas no destino da obra", prolongados, ainda segundo Borges, na nação brasileira, "que não é menos herdeira de Camões do que o próprio Portugal"s.

Camões ajudou (e de que maneira!) a construir de si mesmo um retrato e com ele um imaginário semanticamente sobredeterminado, onde se expressam dualidades e mágoas carregadas de densidade humana. São bem conhecidos os versos finais d'Os Lusíadas, menos desinteressados do que se julga, quando, dirigindo-se ao monarca (como quem diz: ao poder político), o épico diz de si mesmo: "Pera servir-vos, braço às armas feito, / Pera cantar-vos, mente às Musas dada; / Só me falece ser a vós aceito, / De quem virtude deve ser prezada." (Os Lusíadas, $\mathrm{X}, 155^{\circ}$ ). E está também na epopeia uma referência ao naufrágio que pode até ser conveniente invenção do poeta:

Este receberá, plácido e brando,

No seu regaço os Cantos que molhados

Vêm do naufrágio triste e miserando,

Dos procelosos baxos escapados,

Das fomes, dos perigos grandes, quando

Será o injusto mando executado

Naquele cuja Lira sonorosa

Será mais afamada que ditosa. (Lus., X, 128)

7 A questão do exílio (e também do exílio de Camões) foi já objeto de várias análises. Veja-se, por exemplo, o muito abrangente estudo de Maria José de Queiroz, Os Males da Ausência ou a Literatura do Exílio. Rio de Janeiro: Topbooks, 1998, pp. 149-157.

8 Jorge Luis Borges, Destino e obra de Camões. Buenos Aires: Embaixada de Portugal, 2001, pp. 29 e 42. Este é o texto transcrito de uma conferência proferida por Jorge Luis Borges, em Buenos Aires, a 19 de junho de 1972, curiosamente por iniciativa de Maria Julieta, filha de Carlos Drummond de Andrade.

9 Esta e as citações que se seguem são feitas pela edição de Álvaro Júlio da Costa Pimpão (Lisboa: Instituto de Alta Cultura, 1972). 
Este de que fala o poeta é o rio Mekong. Nele sobrenadam perigo e miséria, desdita e sofrida injustiça. Perante tanta desgraça não espanta que a poesia do romantismo se tenha muito rapidamente apropriado destes ingredientes literários, temperados de heroísmo e de conflitualidade bem apetecíveis. Antes ainda do poema narrativo que começou a consagrá-lo, Garrett escreveu, em 1815 (aos 16 anos, para que conste), um soneto em que ecoa o modelo de Bocage ("Camões, grande Camões...”), soneto também de índole narrativa sobre o poeta náufrago, não certamente por ser náufrago, mas por ser poeta:

\section{Cedendo à fúria de Neptuno irado}

Soçobra a nau que o gran tesouro encerra;

Luta co'a morte na espumosa serra

O divino cantor do Gama ousado.

Ai do Canto mimoso a Lísia dado!...

Camões, grande Camões, embalde a terra

Teu braço forte, nadador aferra,

Se o Canto lá ficou no mar salgado.

Chorai, Lusos, chorai! Tu morre, ó Gama,

Foi-se a tua glória... Não; lá vai rompendo

Coa dextra o mar, na sestra a lusa fama.

Eterno, eterno ficará vivendo:

E a torpe inveja, que inda agora brama,

No abismo cairá do Averno horrendo. ${ }^{10}$

3. Avanço, a partir daqui, para outros desenvolvimentos: para a ponderação do escritor (em geral) como personagem; para a análise da elaboração de Camões como personagem em histórias da literatura; para a sua reelaboração

10 Almeida Garrett, Lírica de João Mínimo, em Lírica Completa. Lisboa: Arcádia, 1971, pp. 209-210. Tem precisamente o título Camões, grande Camões... a recolha de poemas organizada por António Ruivo Mouzinho (Porto: UNICEPE, 2002) que bem atesta a vastíssima e muito antiga fortuna literária do autor d'Os Lusíadas. 
como personagem ficcional stricto sensu; por último, para uma reflexão acerca da história literária e da sua apetência pela personalidade do escritor.

Esta última questão é central na minha indagação. Resumo-a assim: por que razão as histórias da literatura (ou pelo menos algumas delas, como veremos) trabalham a figura do escritor como se de uma personagem se tratasse? Tenho para isto, desde já, três explicações que me parecem plausíveis. Uma explicação de ordem metodológica, relacionada com aquilo a que chamei um dos pecados da história literária convencional, o do biografismo: desse ponto de vista, acredita-se que a caracterização da pessoa-escritor conduz (se é que conduz) aos sentidos da obra. Uma explicação de ordem epistemológica e operativa que já introduzo e a que voltarei: a personagem, enquanto categoria estruturante da narrativa, viabiliza modos específicos e consistentes de conhecimento do fenómeno literário, sem que assim se incorra no tal vício do biografismo. Uma explicação de ordem cultural e, por assim dizer, transnarrativa: a literatura (e em especial a narrativa literária) que tem trabalhado o escritor como personagem, sugere e desencadeia um semelhante tratamento na história literária; esta apodera-se do escritor e faz dele uma personagem do grande romance da história da literatura. É por este último caminho que vou continuar.

Proponho, para já, uma espécie de epígrafe que é também uma paráfrase. Assim: "eu não sou propriamente um escritor personagem, mas uma personagem escritor, para quem o romance foi um outro berço." Não ofenderei a cultura de quem me lê identificando texto que origina a paráfrase. O que ela insinua é que algumas ficções narrativas cultivaram um tipo de personagem (o escritor) que passou a fazer sentido a partir do tempo em que o "homem de letras" ganhou um poder simbólico que nalguns casos (Alexandre Herculano, Vítor Hugo, Machado de Assis, Zola e outros) chegou a ser considerável; curiosamente, mas não por acaso, esse foi também o tempo em que a história literária deu os seus primeiros passos. ${ }^{11}$

Um exemplo sugestivo: no capítulo VI d'Os Maias, quando está para começar um jantar que se quer chique, "a porta envidraçada abriu-se de golpe":

11 O Dictionnaire des types et caractères littéraires (Paris: Fernand Nathan, 1978) de C. Aziza, C. Oliviéri e R. Strick consagra um verbete (pp. 62-63) à personagem escritor. 
E apareceu um indivíduo muito alto, todo abotoado numa sobrecasaca preta, com uma face escaveirada, olhos encovados, e sob o nariz aquilino, longos, espessos, românticos bigodes grisalhos: já todo calvo na frente, os anéis fofos de uma grenha muito seca caíam-lhe inspiradamente sobre a gola: e em toda a sua pessoa havia alguma coisa de antiquado, de artificial e de lúgubre. ${ }^{12}$

Esta entrada de rompante é já de si o anúncio vibrante de um temperamento peculiar e, evidentemente, romântico, que é o do escritor feito personagem de ficção. É como tal, quero dizer, como escritor, que o protagonista do romance o identifica e reconhece: "Era ele! o ilustre cantor das Vozes de Aurora, o estilista de Elvira, o dramaturgo do Segredo do Comendador."

Este escritor e estes textos não existiram na realidade da vida pública e cultural portuguesa do século xix. Ou então, dirão outros, se forem pertinentes as acusações que Eça teve que enfrentar, Tomás de Alencar (é dele que se trata n’Os Maias) é a transfiguração ficcional de um escritor que realmente existiu e se chamou Bulhão Pato. No tempo de Eça e no tipo de romance a que Os Maias correspondiam, era cedo para um exercício de metalepse tão ousado como fazer o escritor real invadir o mundo ficcional. Noutros termos: fazer de Bulhão Pato o participante efetivo no jantar literário e na ação d'Os Maias - gesto que, por outro lado, seria um tanto melindroso, sendo aquela personagem o que ela tinha que ser. Conhecendo-se alguns embaraços que, por estas e por outras, Eça enfrentou, vale a pena dizer: já basta o que basta. Ou então, encaminhando-me para o que importa aqui: fique o poeta Tomás de Alencar como personagem de romance e faça-se do poeta Bulhão Pato personagem da história da literatura. Decerto que ele não o foi tanto como outros (Camões, de quem falarei de novo), por escassez de densidade humana e de dimensão literária e não por falta de impulso narrativo das ditas histórias da literatura. Por isto e ainda por outros condicionamentos biográficos a que voltarei.

Este motivo - o do escritor como personagem de ficção - não se esgota obviamente aqui, nem no que diz respeito a $\mathrm{Eça}^{13}$, nem no que toca à literatura

12 Cf. A. José Saraiva e Ó. Lopes, História da Literatura Portuguesa. 12a ed. Porto: Porto Editora, 1982, pp. 323-324.

13 No caso de Eça, aquele que, como às vezes se diz, poderia ter sido o seu grande romance trata precisamente do trajeto formativo de um escritor falhado: A Capital! (Começos duma Carreira). Ana Isabel Pereira consagrou uma dissertação de mestrado ao tema A figura do escritor na ficção queirosiana. Coimbra: Faculdade de Letras, 1999. 
coeva e à dos tempos que lhe sucederam. Mais: as pulsões pós-modernistas que têm induzido engenhosos exercícios metaficcionais convidam a problematizar vários aspetos da própria narrativa em função da figura do escritor inscrito na ficção, seja ele uma pura figura ficcional, seja uma projeção metaléptica do escritor real. Não vou, evidentemente, fazer o elenco, de resto inesgotável, de tais aventuras. Remeto para quem já o fez, deixo indicado, para navegações várias, o amplo rio que daqui se avista e limito-me a apontar alguns exemplos que me desafiam: Eça personagem de romances da literatura em língua portuguesa ${ }^{14}$, Ricardo Reis protagonista do romance de José Saramago que leva o seu nome no título, Camilo Castelo Branco e Bernardo Soares personagens de romances de Mário Cláudio e Florbela Espanca biografada em regime paraficcional por Agustina Bessa Luís. Estes e ainda um caso recente, de novo da autoria de Mário Cláudio: a extensa biografia de Tiago Veiga, um mal conhecido escritor português que terá vivido entre 1900 e 1988 e que, de tão pouco conhecido, talvez seja, por fim, uma hábil invenção de quem o concebeu como figura em diálogo com importantes vultos da cultura portuguesa e europeia do século $\mathrm{xx}^{15}$. O poeta Carlos Fradique Mendes não andou longe desta ambivalência.

É claro que há personalidades especialmente convidativas para tais exercícios. Penso nos escritores de quem se diz que são personagens de si mesmos (Garrett e Pessoa) ou naqueles cujas vidas dariam (e deram) romances, designadamente o já citado Camilo a propósito de quem Aquilino Ribeiro escreveu uma biografia que ostenta um título significativo: O Romance de Camilo (1956). Por outro lado, a sedução que o escritor exerce sobre o escritor (assim mesmo: o escritor sobre o escritor) favorece incursões no tema da escrita, do seu potencial de revelações e dos jogos de sombras que lhe andam associados, não raro com ressonâncias autobiográficas. Apetece perguntar: quem se esconde por detrás daquele pintor falhado que, no final do Manual de Pintura e Caligrafia de Saramago, se descobre escritor? E quem vislumbramos naquele obscuro Raimundo Silva, revisor de imprensa que, na História do Cerco de Lisboa do mesmo Saramago,

14 Cf. Maria de Fátima Marinho "A figura de Eça de Queirós em três romances contemporâneos", in Voz Lusíada, 16, $1^{\circ}$ sem., 2001, pp. 88-102. Os três romances analisados são As Batalhas do Caia, de Mário Cláudio, A Visão de Túndalo, de Miguel Real, e Nação Crioula, de José Eduardo Agualusa.

15 Mário Cláudio, Tiago Veiga. Lisboa: Pub. Dom Quixote, 2011. 
se atreve a reescrever em registo ficcional um episódio decisivo da História de Portugal? ${ }^{16}$

4. Estão adquiridas e têm sido aprofundadas pelos estudos narrativos algumas noções basilares, respeitantes ao poder cognitivo e representacional da narrativa. Tais noções, vindas de campos de análise que não a teoria da narrativa pura e dura, são legitimadas por uma certa homologação da ficção narrativa com a historiografia. De forma mais clara: trata-se de sublinhar, na historiografia, uma predominante vocação narrativística que é entendida como inerente aos seus propósitos e às suas finalidades comunicativas. Sublinho, assim, com Louis O. Mink (e este com Arthur Danto e Robin Collingwood), a dimensão cognitiva da narrativa, bem como a capacidade que História e ficção possuem para nos levarem à compreensão do mundo e das $\operatorname{coisas}^{17}$; sigo Jerome Bruner na análise de princípios estruturantes da narrativa como instrumentos de construção da realidade ${ }^{18}$; e acompanho o pensamento de Hayden White, que sublinha "the value attached to narrativity itself, especially in representations of reality of the sort embodied in historical discourse". 19

É agora que cabe perguntar: como existem e para que existem os escritores enquanto personagens na história da literatura? E em termos ligeiramente distintos: como as diferentes histórias da literatura vão configurando e refigurando essas personagens? Mais: em que medida o tratamento do escritor como personagem chega a interferir na composição do cânone, em particular quando esse escritor nele ocupa um lugar central?

16 Por razões relativamente óbvias, fico-me (e em termos meramente indicativos) pela literatura portuguesa, sabendo embora que noutras literaturas não faltam casos similares a estes.

17 Cf. Louis O. Mink, "Narrative form as a cognitive instrument", in R. H. Canary e H. Kozick (eds.), The Writing of History. Literary Form and Historical Understanding. Madison: The Univ. of Wisconsin Press, 1978, pp. 129-149; id., "History and Fiction as Modes of Comprehension", in New Literary History, vol. 1, 3, Spring 1970, pp. 541-558.

18 Jerome Bruner, "The Narrative Construction of Reality, Critical Inquiry, 18, Autumn, 1991, pp. 1-21. Escreve Bruner: "What I have tried to do in this paper is to describe some of the properties of a world of "reality" constructed according to narrative principles. In doing so, I have gone back and forth between describing narrative mental "powers" and the symbolic systems of narrative discourse that make the expression of these powers possible." (p. 21).

19 H. White, "The value of narrativity in the representation of reality". The Content of the Form. Narrative Discourse and Historical Representation. Baltimore and London: The Johns Hopkins Univ. Press, 1987, p. 24. 
Camões, é claro, vem a ser uma figura paradigmática na cultura portuguesa, capaz de, por essa sua condição paradigmática, levar a outras reflexões semelhantes à que vou fazer. Por exemplo, as que podem ser formuladas a propósito de Cervantes, na cultura espanhola, de Shakespeare, na cultura inglesa, de Dante, na italiana, de Goethe, na alemã, de Victor Hugo, na francesa. E assim por diante, até chegarmos a perguntar o seguinte: quando dizemos "o bruxo do Cosme Velho" estamos ainda a falar do maior romancista brasileiro ou de uma espécie de personagem ficcional construída pela história literária? ${ }^{20}$

Chamarei agora a atenção para alguns casos práticos em que Camões é motivo de elaboração histórico-literária, com destaque para considerações de índole biográfica, lá onde se vai construindo uma entidade com contornos de personagem. Recorro, para o fazer, a três histórias da literatura portuguesa, bem diferentes nos valores a que se reportam e nos tempos em que foram compostas ou recompostas: a de Mendes dos Remédios, datada da passagem do séc. xix para o séc. xx; a de Fidelino de Figueiredo, especialmente o volume História da Literatura Clássica (I Época - 1502-1580), em reedição publicada no semiexílio brasileiro do autor; a de António José Saraiva e Óscar Lopes, na segunda metade do século xx, consubstanciando uma História da Literatura Portuguesa que foi incómoda, até 1974, para um regime político que a considerava tão subversiva (assim se dizia então) como os seus autores.

Para Mendes dos Remédios, a vida de Camões é (retenho este dado) um conjunto de circunstâncias não esclarecidas, abrindo caminho a conjeturas e a hipóteses várias. Depois disso, o que avulta no trajeto biográfico camoniano são episódios e traços comportamentais que a seguir destaco, com citações: uma "vida aventurosa e recortada de desgostos, que não mais cessaram de o perseguir"; uma vida amorosa que levou a que fosse afastado da corte; um "génio altivo e independente"; a passagem por África onde "deu asas ao seu temperamento belicoso"; a decisiva viagem para a Índia, sublinhando-se que, em Goa, Camões teve "mais ocasiões de empunhar a espada do que a pena"; a vida de martírios e um naufrágio no decurso do qual "a custo ele se salvou e à obra, que tão preciosa era"; o regresso à Pátria e a pobreza, "depois de dezasseis anos de desterro".

20 É praticamente como uma personagem de ficção que um poema de Drummond de Andrade ("A um bruxo, com amor") evoca Machado de Assis, de mistura com a referência às personagens femininas que povoam a sua obra. 
Quase concluindo: "Restava-lhe a sua mãe, a quem jubilosamente, decerto mostraria a obra que era seu orgulho e seu enlevo". Por fim: Camões, sepultado em circunstâncias de abandono que o historiador pormenoriza, tendo morrido com a Pátria (como ele mesmo terá confessado), no mesmo ano de 1580 em que se deu a união das coroas ibéricas ${ }^{21}$. Não é este, evidentemente, um final feliz, nem para o poeta, nem para Portugal; mas contrapõe-se o sofrimento, o descaso e a miséria, que o historiador não se cansa de sublinhar, à feição já mítica de uma figura cujo génio contrasta com tanta infelicidade, em biografia marcada (é Mendes dos Remédios quem o lembra) pela dualidade poeta-soldado. Não é preciso muito mais para que a vida de Camões seja contada como um agitado romance de aventuras. $^{22}$

Fidelino de Figueiredo segue um trajeto parecido - primeiro, a vida; depois, a obra -, mas formula considerações que há que ter em conta. A vida de Camões é o que já se sabe: estudos em Coimbra, amores em Lisboa, guerras em África, desterro no Oriente, viagens atribuladas, com o tal naufrágio de permeio. No regresso a Portugal, em 1570, vinham Os Lusíadas. Tudo resumido, persiste o estigma da infelicidade: uma "existência penosa, que em 1580 terminava, quando terminava a autonomia política da sua pátria, cujos altos feitos calorosamente glorificara". Entretanto, Fidelino de Figueiredo avisa: faltando ao historiador da literatura muitos elementos que permitam reconstituir a personalidade de Camões, só por "imaginação artística, fantasia de romancista", pode essa personalidade ser desenhada. Sendo assim, sublinha-se, em jeito de conclusão, que "há sempre qualquer coisa de irreverente mau gosto, quase sacrílego, em tomar a personalidade de quem fez literatura de génio para pretexto de má literatura". Como quem diz: por muito narrativizada e mesmo romanceada que seja a história da literatura, há limites para tudo. ${ }^{23}$

Foi dentro desses limites que António José Saraiva e Óscar Lopes procuraram conter as breves referências à biografia de Camões, na sua História da Literatura Portuguesa. Valorizando, como princípio metodológico geral, os componentes

21 Cf. Mendes dos Remédios, História da Literatura Portuguesa desde as Origens até à Atualidade. 6a ed. Coimbra: Atlântida Liv. Editora, 1930, pp. 144-147.

22 É em parte nesse registo que a banda desenhada tem aproveitado a vida de Camões. Veja-se o recente trabalho de Jorge Miguel, Camões. De vós não conbecido nem sonhado? Lisboa: Plátano, 2008.

23 Cf. Fidelino de Figueiredo, História da Literatura Clássica. I Época (1502-1580). $3^{\mathrm{a}}$ ed. rev. São Paulo: Editora Anchieta, 1946, pp. 245-249. 
sociais, culturais, ideológicos e políticos que enquadram a literatura e os fenómenos artísticos (é conhecida a que então era a filiação marxista de ambos os autores), Saraiva e Lopes operam de forma muito cautelosa: destacam o ambiente cultural e o contexto político em que Camões se moveu e ficam-se por testemunhos minimamente fidedignos, incluindo os do próprio poeta. "Em alguns passos da obra", observam, "atribui Camões a responsabilidade dos seus desastres a amores infelizes; mas não passa de romance biográfico sem fundamento tudo o que desde o séc. xvir até ao $1^{\circ}$ quartel do século xx se tem imaginado acerca de desterros ou perseguições devidos a amores infelizes por uma alta dama do Paço (...)". ${ }^{24}$

Nem todos, enquanto historiadores (é esse o plano em que por agora me encontro), seguiram esta contenção. As muitas lacunas que marcam o escasso conhecimento da vida de uma tão fascinante personalidade são tentadoras e mesmo eventualmente lucrativas, quando se quer exercitar aquela "fantasia de romancista" de que falou Fidelino de Figueiredo ${ }^{25}$. Em termos mais rigorosos: quando surgem numa biografia inúmeros pontos de indeterminação, para usar a noção consagrada pela fenomenologia da literatura, espaços em branco que a imaginação do historiador ousado completa. Seguindo Ingarden, Wolfgang Iser acentuou o papel pró-ativo dos atos de leitura, uma vez que a assimetria de texto e leitor convida a que este preencha os brancos que a ficção, pela sua natureza, deixa em aberto $^{26}$; ora o fechamento que a história literária persegue parece metodologicamente incompatível com tal preenchimento ${ }^{27}$. Em termos mais claros: se a história literária não conseguiu apurar o que lhe era necessário, o historiador não deverá ir além do que é conhecido. De maneira talvez demasiado esquemática, dir-se-á que o preenchimento dos vazios da vida de um escritor pode ter dois nomes: falsificação, no caso da historiografia literária; ficcionalização, no campo da criação literária.

24 Cf. A. José Saraiva e Ó. Lopes, História da Literatura Portuguesa. $12^{\mathrm{a}}$ ed. Porto: Porto Editora, 1982, pp. 323-324.

25 Justamente: uma personalidade controversa e não raro posta em causa no que toca ao rigor científico dos seus trabalhos, José Hermano Saraiva, foi autor de uma muito vendida Vida Ignorada de Camões, trabalho em que o apelo do desconhecido é mais forte do que o impulso para a fixação consistente dos factos histórico-literários.

26 Cf. W. Iser, El acto de leer. Madrid: Taurus, 1987, pp. 255 ss.

27 Cf. David Perkins, Is Literary History Possible?, ed. cit., p. 47. 
5. Mas nem tudo é necessariamente assim nítido, conforme alguma literatura pós-modernista tem mostrado e tal como deixei sugerido quando antes falei naquelas engenhosas construções metaficcionais que tratam o escritor como personagem. Ainda há pouco, uma estudiosa de Camões, Maria Vitalina Leal de Matos, publicou um romance biográfico (Camões - Este Meu Duro Génio de Vinganças) em que a sua experiência de camonista se alia ao processo de construção de uma personagem-Camões em regime desenvoltamente ficcional. ${ }^{28}$

Este é um exemplo (porventura o mais recente, a menos que considerássemos o recentíssimo Uma Viagem à Índia de Gonçalo M. Tavares), entre muitos outros, com uma nota de curiosidade adicional e que nos chega de onde menos se esperaria, de um ponto de vista por assim dizer institucional: do interior dos estudos camonianos, lá onde predominam sérias e ponderosas preocupações com o rigor dos factos histórico-literários, quando é deles que se trata. Para além disso, a hipótese que quero colocar, antes de evocar alguns outros casos bem conhecidos, é a seguinte: a literatura - a de ficção narrativa ou outra - que tem adotado Camões como personagem não será imune, bem pelo contrário, à longa tradição e ao potencial narrativístico de uma história literária que tem trabalhado o escritor como se ele fosse personagem de um relato como tal estruturado. Refiro-me a este escritor de que tenho falado e também a outros: na sua já clássica Vida e Obra de Eça de Queirós, João Gaspar Simões (que além de biógrafo e crítico literário foi também romancista, ainda que menor ${ }^{29}$ ) narra assim os momentos finais da vida de Eça: "É encomendado para o Instituto Pasteur um soro que lhe será injetado, caso ainda venha a encontrá-lo com vida. Os olhos do doente cintilam. Talvez esteja ali a saúde. E uma esperança lhe faz entreabrir os lábios

28 São de outra ordem e motivação (da ordem da paródia hipertextual, da desconstrução do poema épico e das derivas a que ele deu lugar) dois outros textos do nosso tempo. Um deles intitula-se exatamente Os Lusíadas (1977) e é da autoria conjunta de Alface (pseudónimo de João Alfacinha da Silva) e Manuel da Silva Ramos. O outro, talvez injustamente esquecido, é o longo poema As Quibíricas, saído quando das (e de certa forma contra as) celebrações oficiais do quarto centenário (1972) da publicação d'Os Lusíadas; assinado por Frei Ioannes Garabatus, o poema foi, de facto, escrito pelo pintor António Quadros (1933-1994) e surgiu com um prefácio de Jorge de Sena. Convém lembrar que Sena foi não apenas eminente estudioso da obra camoniana (num registo psicológico com alguma coisa de identificação), mas também autor de um conto ("Super Flumina Babylonis", em Antigas e Novas Andanças do Demónio) protagonizado pelo Camões poeta de "Sôbolos rios que vão".

29 Romancista menor, mas romancista, autor, por exemplo, de Pântano (1940), Um Marido Fiel (1942) e Internato (1946). 
num débil e fugaz sorriso"30. Por menos do que isto o romancista Eça interpelou o historiador Oliveira Martins: "Estavas lá? Viste?"31. Mas há mais: sendo aquele trecho (e muitos outros, além daquele) puro romance, ele nem sequer é muito original. Já antes de Gaspar Simões, Vianna Moog operara um cruzamento muito significativo, para o que aqui importa: a biografia literária de Eça, de que Moog é autor, frequentemente inclui microrrelatos e diálogos que vêm da própria obra do escritor, num exercício em que se misturam as águas da história literária com as da ficção. ${ }^{32}$

Em meu entender é da história literária e do imaginário camoniano por ela fomentado que se nutrem muitos dos textos (e certamente não só na literatura portuguesa $^{33}$ ) que tratam de explorar os traços mais sedutores e mais singularmente "heroicos" da personalidade de Camões, traços que não raro são metonimicamente associados ao destino coletivo português. Em boa parte, esses traços provêm do romantismo, invadiram algumas histórias da literatura e prolongaram-se para além delas. É consabidamente romântico, narrativizado e ficcional o poema Camões que Garrett compôs em contexto e em momento pessoal favorecedores de um movimento de identificação nada modesto ${ }^{34}$; e em parte é também romântico e narrativo o Camões que Miguel Torga celebrou num dos Poemas Ibéricos ("Chamar-te génio é justo, mas é pouco./Chamar-te herói, é dar-te um só poder./ Poeta dum império que era louco,/Foste louco a cantar e louco a combater."35). Não é menos personagem e é até, em certa medida, mais incorporadamente

\footnotetext{
30 J. Gaspar Simões, Vida e Obra de Eça de Queirós. $3^{\text {a }}$ ed. Amadora: Liv. Bertrand, 1980, p. 675.

31 Eça de Queiroz, Correspondência, II. Organização e anotações de A. Campos Matos. Lisboa: Caminho, 2008, p. 261.

32 Cf. Vianna Moog, Eça de Queirós e o Século XIX. $6^{\mathrm{a}}$ ed. Porto Alegre: Instituto Estadual do Livro, 2006 (a primeira edição é de 1938).

33 Em 1932 publicou o escritor holandês J. J. Slauerhoff um romance há alguns anos traduzido para português (O reino proibido. Lisboa: Teorema, 1997) em que se encontra uma personagem moldada sobre o poeta Camões; segundo Patrícia Couto e Arie Pos, responsáveis por aquela tradução, uma das fontes usadas pelo romancista (personalidade complexa que desenvolveu um grande fascínio de autoidentificação por Camões) foi a História da Literatura Portuguesa Ilustrada de Albino Forjaz de Sampaio ("Camões e Macau num romance neerlandês", in Revista Camões, no 7, 1999, pp. 107-118).

34 Refiro-me ao facto de Garrett ter composto o poema Camões no exílio, muito marcado pela figura do poeta perseguido: a nota B do autor à primeira estrofe do canto I (na segunda edição) é a este propósito muito elucidativa. Num ensaio capital sobre esta matéria, escreveu Eduardo Lourenço: "Le poème Camoëns est le premier grand texte portugais tissé avec le texte camonien" ("Le romantisme et Camoëns", in Nós e a Europa ou as duas razões. $2^{\mathrm{a}}$ ed. Lisboa: Imp. Nacional-Casa da Moeda, 1988, p. 108).

35 Poema "Camões", em Poemas Ibéricos (Poesia Completa. Lisboa: Pub. Dom Quixote, 2000, p. 721).
} 
narrativo o Camões em forma de estátua que aparece nas linhas finais d'O Crime do Padre Amaro, com "a Epopeia sobre o coração, a espada firme" ${ }^{36}$, nas vésperas do terceiro centenário da sua morte, efeméride contaminada por claros propósitos políticos e ideológicos. Ou o Camões de Cesário Verde, nesse mesmo tricentenário, lembrado numa estrofe d' "O Sentimento dum Ocidental":

E evoco, então, as crónicas navais:

Mouros, baixéis, heróis, tudo ressuscitado!

Luta Camões no Sul, salvando um livro a nado!

Singram soberbas naus que eu não verei jamais! $!^{37}$

É ainda no mesmo tricentenário, compondo oitavas de sabor camoniano, no tom sombrio que se ajustava ao estado da Pátria decadente, que Gomes Leal alegoriza a miséria do épico regressado a Portugal. Ao abrir o canto II d'A Fome de Camões (título que diz muito daquilo que o longo poema narrativo quer ser) e imediatamente antes de o relato dar corpo de personagem sinistra à fome do poeta já moribundo, podemos ler:
É alta a noite. A lâmpada vacila, como um pranto, na vasta enfermaria.
Um marmóreo suor frio cintila
sobre a fronte do Génio, na agonia.
O Génio vai morrer; sobre a pupila
treme-lhe um pranto à luz baça e sombria,
mais triste do que o luto duma sina,
e um soluço através duma ruína. ${ }^{38}$

36 Eça de Queirós, O Crime do Padre Amaro. Lisboa: Presença, 2005, p. 398.

37 O Livro de Cesário Verde. $15^{a}$ ed., Lisboa: Minerva, 1970, p. 94 . O espaço camoniano do Chiado reaparece noutro passo do mesmo poema, esboçado, embora, nos termos difusamente impressionistas que a poesia de Cesário cultiva: "Mas, num recinto público e vulgar,/Com bancos de namoro e exíguas pimenteiras,/Brônzeo, monumental, de proporções guerreiras,/Um épico doutrora ascende, num pilar!” (ed. cit., p. 97).

38 E na estrofe seguinte: "Junto do leito uma mulher estranha,/com grandes olhos tristes e parados,/contempla-lhe o suor frio que o banha,/e abraça-o com seus braços descarnados./Como um sol que se põe numa montanha,/são frios os seus olhos encovados,/hirta, severa, trágica a postura,/como imagem d'antiga sepultura." (Gomes Leal, A Fome de Camões. Lisboa: Pub. Culturais Engrenagem, 1979, p. XXI). 
6. Camoniamente dir-se-ia: "Mudam-se os tempos, mudam-se as vontades./ Muda-se o ser, muda-se a confiança". Para aquilo que me interessa, digo: mudam-se os tempos, reescreve-se a figura do poeta e deste modo se vai mudando alguma coisa do seu ser. Acontece assim até mesmo em cenários culturais muito distantes do centro de onde derivou a figura de Camões e das normas, mesmo que difusas, do campo literário e dos seus protocolos institucionais. Recordo o que disse Borges (a nação brasileira "não é menos herdeira de Camões do que o próprio Portugal") e remeto, mesmo que brevemente, para um trabalho de Gilberto Mendonça Teles acerca da presença de Camões na poesia brasileira; nessa e também em relatos da literatura popular, sobretudo nordestina, não raro de expressão oral ou então fixada em romances de cordel. É nesses relatos que Camões é refigurado como personagem-tipo: o poeta engenhoso, de palavra fácil e sentença sábia, sempre pronto a responder a desafios que aquelas qualidades facilmente superam. E mais: capaz também de conjugar (ou mesmo de fundir) esses talentos com os de uma outra figura de poeta, o Bocage das anedotas brejeiras. ${ }^{39}$

Não é por aí, contudo, que desejo seguir, mas antes pelo caminho que leva a dois escritores portugueses da atualidade, José Saramago e António Lobo Antunes. O primeiro, já citado aqui como exemplo de apetência pela elaboração metaficcional de escritores como personagens, consagrou a Camões não um relato, mas um texto dramático, Que farei com este livro? (1980); é do destino post mortem de Camões e da sua epopeia, sob o signo do regresso à Pátria e da confrontação com os poderes instituídos, que trata um drama de cuja leitura depende "o trânsito para o futuro". E aí de novo o que está em causa é, na figura e na desfortuna do poeta, a problematização da literatura e do seu destino. Nesse sentido, opera-se uma transferência de foco e declara-se: o protagonista de Que farei com este livro? "já não é Luís Vaz de Camões, mas o destinatário do seu livro e sua maior razão de ser (e agora também desta peça que o toma para ponto de partida): o povo português". ${ }^{40}$

39 Cf. Gilberto Mendonça Teles, Camões e a poesia brasileira. 2a ed., Brasília/São Paulo: Ed. Quíron/Inst. Nacional do Livro, 1976, pp. 275 ss. Dois exemplos: de José Costa Leite, O Casamento de Camões com a filha do rei e de Severino G. de Oliveira, As perguntas do rei e as respostas de Camões.

40 Luiz Francisco Rebello, "Prefácio (talvez) supérfluo" a Que farei com este livro? 2a ed. Lisboa: Caminho, 1988, p. 15. 
O caso de Lobo Antunes é, para o presente contexto, mais significativo: refiro-me ao romance As Naus e ao papel que nele cabe a "um homem de nome Luís a quem faltava a vista esquerda". Mas antes sublinho que aquele romance, publicado em 1988, constitui um dos relatos paradigmáticos do quem tem sido, em Lobo Antunes, a narrativa de Portugal em regime ficcional, num momento propício a efabulações pós-modernistas e, tendo em vista a situação histórica portuguesa, pós-coloniais. Já o tenho dito: quando se fizer a história do Portugal do último quartel do século xx, alguns dos romances de Lobo Antunes ocuparão nela um lugar de destaque pela forma como dão testemunho, nessa modelização ficcional, de um tempo histórico de desengano e de revisão de valores, de regresso à Europa e de traumas legados pelo Império extinto, de figuras amargas e de episódios grotescos vividos numa atmosfera de fim de século com a crepuscular coloração de um epílogo civilizacional. É, então, de anti-heróis que se constrói a ficção de Lobo Antunes desde o romance Os Cus de Judas; e é um desses anti-heróis, o tal Luís sem a vista esquerda, que obriga a repensar a epopeia em função do que é uma sua antífrase, ou seja, um romance intitulado originalmente O Regresso das Caravelas e depois, por razões acidentais, As Naus ${ }^{41}$.

Neste, não é só o olho vazado de Camões que é recolocado, passando para o lado esquerdo do rosto (como se um espelho provocasse a inversão); o próprio sentido da epopeia é revisto, num tom que oscila entre a paródia, o sarcasmo e a amargura da História perdida. O tal Luís, que abre o segundo capítulo do romance, é, afinal, um retornado (como nos anos 70, a seguir à descolonização, se dizia), perdido num cais de Lisboa; ele traz consigo os poucos haveres que lhe restaram, incluindo a urna com os restos do pai, sonha com a África perdida e com "os braços noturnos das negras carecidas", e joga às cartas com um maneta espanhol também de regresso à Europa, um antigo soldado chamado Miguel de Cervantes. Tudo ponderado, trata-se de um novo naufrágio, agora simbólico e com a feição de uma tragédia histórica irreversível. Do poema épico nada se salva; ou então fica dele apenas esta espécie de antiepopeia em que se enceta o processo crítico do Portugal pós-imperial, incapaz, por fim, de se libertar da memória já incómoda de uma grande personagem chamada Luís de Camões.

41 Acontece que o título O Regresso das Caravelas estava registado em nome de outro escritor (Vittorio Káli) e Lobo Antunes foi obrigado a encontrar um título alternativo. A edição em francês manteve, contudo, Le retour des caravelles. 
No que depender deste romance, essa memória incómoda pode mesmo chegar ao extremo de riscar a epopeia do cânone, se as histórias da literatura futuras se louvarem na ficção meta-histórica que Lobo Antunes compôs.

7. Algumas breves reflexões finais que, mais do que respostas, deixam interrogações e também propostas de trabalho relacionadas com o que tem sido o eixo deste texto: a verificação de que uma categoria narrativa (no caso: a personagem escritor, ou melhor, o escritor realmente existente, configurado como personagem) assume uma presença importante na história literária e na construção do imaginário que ela alimenta. A proeminência histórico-literária da personagem não deve ignorar o que George Steiner notou: "Si la historia es la circunferencia que describe un acto literario, artístico o textual para dar forma, este acto, a su vez, modela y anima lo que postulamos como historicidad recapturable y documentada"; e acrescenta Steiner: "nuestras reconstrucciones experimentadas del pasado son "ficciones de verdad" gramaticales y textuales. Están talladas a partir de las disponibilidades del pretérito. Ninguna verificación final externa está vinculada a ellas.”² Como se Steiner nos dissesse: façamos de Camões e de Shakespeare, de Balzac e de Castro Alves, de Machado de Assis e de Eça, de Camilo Castelo Branco e de Tolstoi, de Baudelaire e de Fernando Pessoa grandes personagens de uma ficção de verdade chamada história da literatura.

A isso somos conduzidos pelo facto crucial de as propriedades constitutivas da personagem implicarem a narratividade como cenário de enquadramento funcional e discursivo. Nesse sentido, podemos dizer: assim como a personagem é virtualmente narrativa (isto é: carece do relato para existir), inevitavelmente a história literária que a acolhe e que a trabalha como instrumento heurístico cultiva uma correlata dinâmica narrativa. Chamo a atenção para três aspetos deste ménage à trois personagem-história literária-narrativa. Primeiro aspeto: se há componente que incute densidade histórica à personagem esse componente só pode ser o tempo; e é a narrativa que acentua e dá sentido à vivência humana do tempo (assim falava Paul Ricoeur). Segundo: aquilo a que chamo densidade

42 G. Steiner, Presencias reales. Barcelona: Ediciones Destino, 1991, pp. 202-203. 
histórica da personagem envolve componentes ideológicos e axiológicos que muito convêm a uma história literária que se não faz de forma inocente; ela escolhe, hierarquiza e toma partido (é para isso que tendemos quando distinguimos os grandes escritores dos escritores menores) ${ }^{43}$. Terceiro: a narratividade que, pela via da personagem (embora não só por ela), enforma a história literária favorece a tensão própria do grande enredo de que se tece a história da literatura; e assim, os escritores não são apenas maiores e menores (o que já não seria pouco), mas revelam-se-nos aos pares, em relações de enfrentamento, de complementaridade ou até de conflitualidade a que não ficamos indiferentes.

Dito isto, acrescento o seguinte: ter-se-á notado (ou então nota-se agora) que os nomes que invoquei como potenciais ou efetivas grandes personagens da história literária (Camões, Shakespeare, Baudelaire, Pessoa, etc.) correspondem a escritores do passado, historicamente "resolvidos" e devidamente classificados e arrumados nas estantes que para eles preparámos. Mais: aqueles são nomes que vêm de tempos e de modos de vida em que abundam omissões e lacunas; não os conhecemos em carne e osso, como aconteceu, acontece ou poderá ainda acontecer relativamente a Drummond de Andrade, a Miguel Torga, a Saramago, a Paul Auster, a Lobo Antunes, a Mario Vargas Llosa ou a Gabriel García Márquez. Por tudo isso, parece fazer mais sentido (ou um sentido diferente) a construção daquelas outras personagens-escritores cujos pontos de indeterminação (Ingarden) ou brancos (Iser) autorizam a imaginação do historiador a um trabalho que evita a pergunta embaraçosa de Eça a que antes aludi. Jorge de Sena, notável escritor e eminente camonista, escreveu palavras que confirmam, a respeito de Camões, isto mesmo e outras coisas que aqui já disse: "É certo que pouco ou nada se sabe de concreto acerca desse homem, cujo nascimento, cuja vida, cuja morte e cujos restos mortais são duvidosos, maravilhosamente duvidosos. O que é um convite à imaginação". ${ }^{4}$

43 A escolha e a hierarquização de que aqui se fala está presente também na organização e na lógica da antologia, publicação que à sua maneira trabalha com e para a história literária. Sublinho o significado e os efeitos da escolha antológica lembrando o seguinte: uma antologia da poesia portuguesa do século xx publicada há alguns anos (antologia construída, é certo, de forma peculiar) causou perplexidade e mesmo controvérsia por deixar de fora um escritor como Miguel Torga. O título e o propósito do ensaio introdutório da referida antologia deixam no ar algumas insinuações interessantes: "Desaprender com a história" (cf. Osvaldo M. Silvestre e Pedro Serra, Século de Ouro. Antologia Crítica da Poesia Portuguesa do Século xx. Braga/Coimbra/Lisboa: Angelus Novus \& Cotovia, 2002).

44 Jorge de Sena, "A poesia de Camões", Trinta Anos de Camões: 1948-1978. Lisboa: Edições 70, 1980, p. 17 . 
Mas há mais. Os escritores, digamos, de agora sabem defender-se ou têm quem os defenda das confabulações de uma história literária que, no futuro (se houver um futuro para a história literária), poderia dar deles uma imagem diferente da personagem que eles querem ser ou que alguém quer que eles sejam. Não me adentrarei por este terreno movediço, deixo apenas o alerta para esta questão. Esse alerta decorre do conhecimento que hoje temos da forma de atuar de diversos mecanismos institucionais que incluem, entre outros, os prémios, as validações académicas (às vezes estimuladas pelos próprios escritores), as editoras e as suas máquinas de marketing, os agentes literários, a vigilância dos herdeiros e os lobbies que protegem as minorias ${ }^{45}$. Assim se vai preparando a posteridade do escritor e condicionando a personagem que outros hão de ler numa narrativa chamada história da literatura. Não havia tais mecanismos no tempo de Gil Vicente, de Camões, de Racine, de Baudelaire ou de Fernando Pessoa; e os que existiam (como a proteção mecenática) tinham efeitos diversos, eventualmente menos sinuosos e de menor projeção histórica do que aqueles que mencionei.

Penso que assim, pela via da consagração do escritor como personagem, está vencida uma espécie de aporia ou, no mínimo, um constrangimento metodológico formulado por David Perkins: por um lado, "narrative literary history cannot be wholly adequate as history because it is narrative; por outro lado, "it cannot be very gripping as narrative because it is also criticism and history" ${ }^{\prime 2}$. Acontece que, pelo caminho que tenho seguido, aquele constrangimento deixa de fazer sentido, porque a história literária é narrativa e não se vê que possa ser de outro modo; o próprio Perkins nota que a história literária atual é viável também por ter sido superada uma fratura operativa que há meio século predominava: "literary critics studied rhetoric and fictional representation, and historians (and even literary historians) made representations of the past without considering that these also were rhetorical in form and were even, in many cases, like literary fictions. Now, however, we increasingly see that the past is necessarily transformed in the effort to represent it discursively"47.

45 Alguns destes mecanismos e instâncias de validação estão caracterizados no meu livro O Conbecimento da Literatura (Coimbra: Almedina, 2001 [reimp.], pp. 19 ss).

46 D. Perkins, Is Literary History Possible?, p. 40.

47 D. Perkins, op. cit., p. 19. 
Isto dá resposta a todas as dificuldades da história literária na atualidade? Certamente que não e muito menos são assim resolvidas duas que, por fim, aponto. Uma: a história literária, também por ser narrativa, não se esgota no tratamento da figura singular do escritor; antes dele e envolvendo-o está o sentido da mudança e a feição plural que esta exibe, conforme bem notou Claudio Guillén: "Un punto de vista lineal, secuencial o serial, nos impediria captar las simultaneidades. El sistema en conjunto cambia, pero sólo porque ciertas alteraciones parciales hacen posible ese efecto total. 'æ48 Outra dificuldade: a história literária sempre enfrentará a cruel e perversa obrigação da escolha, que vai de par com a síndrome do esquecimento que é a contraparte inevitável de uma tal escolha; e ambos, escolha e esquecimento, transparecem em gestos e em opções tão díspares como a preparação de planos curriculares, a dimensão das estantes que compramos ou os elencos de autores em coleções que editamos.

Recorro a Eça para bem me explicar e já terminando. Num caricatural episódio do romance $A$ Capital!, alguns conspiradores que se batem pela implantação da República chegam a discutir uma proposta bizarra: pendurar nas paredes da sala onde se reúnem os sócios do clube político os retratos de todos os mártires da liberdade. Proposta difícil de concretizar, conforme argumenta um dos conspiradores, cúmplice, sem o saber, das dificuldades da história literária. Diz ele: "é difícil obter o retrato da maior parte, - a não ser desenhos de fantasia, que por falsos, tendem a produzir indiferença, em lugar de impor a veneração. Além disso, os mártires são inumeráveis, as paredes são só quatro...”49

Assim estamos nós: lutamos contra a indiferença de quem lê as nossas fantasias e temos escassas paredes para tantos mártires da literatura.

48 C. Guillén, Teorias de la historia literaria. Madrid: Espasa Calpe, 1989, p. 261.

49 Eça de Queirós, A Capital! Edição de Luiz Fagundes Duarte. Lisboa: Imprensa Nacional-Casa da Moeda, 1992, p. 299. 